International Journal of Trend in Scientific Research and Development (IJTSRD)

Conference Issue | March 2019 Available Online: www.ijtsrd.com e-ISSN: 2456 - 6470

Fostering Innovation, Integration and Inclusion Through

Interdisciplinary Practices in Management

$\checkmark$

\title{
Innovations in Higher Education for Teaching and Learning using Technology
}

\author{
Dr. Mrs. Sampada Gulavani ${ }^{1}$, Dr. Rajesh Kanthe ${ }^{2}$ \\ ${ }^{1}$ Associate Professor, ${ }^{2}$ Director \\ 1,2Bharati Vidyapeeth Institute of Management, Kolhapur, Maharashtra, India
}

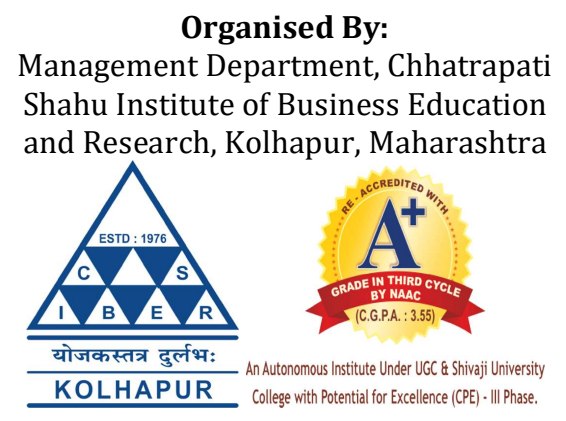

How to cite this paper: Dr. Mrs. Sampada Gulavani | Dr. Rajesh Kanthe "Innovations in Higher Education for Teaching and Learning using Technology" Published in International Journal of Trend in Scientific Research and Development (ijtsrd), ISSN: 24566470, Special Issue | Fostering Innovation, Integration and Inclusion Through

Interdisciplinary

Practices in

Management,

March 2019,

pp.73-75, URL:

https://www.ijtsr d.com/papers/ijt srd23068.pdf

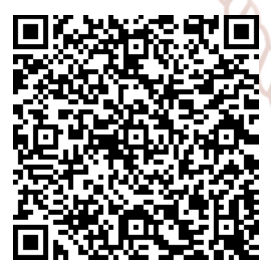

IJTSRD23068

\section{ABSTRACT}

Education is regarded as a process of interaction and interpersonal communication .In twenty first century with the appropriate use of evolving information and communication technologies (ICT), there is innovation in education system. Knowledge and technology plays an important role in teaching and learning methodology. An innovative educator constantly formulate new ways and approaches to teaching and learning to maximize the output. Today since world is moving rapidly into digital media and information, so the role of ICT in education is very important.Higher education in the country is experiencing a major transformation in terms of access, equity and quality. ICT based education causes changes in the educational objectives in the conception of the teaching and learning process. Approaches of technology and innovative teaching techniques in higher education is necessary. Also measures required for technology based education need to be considered. In this regard, the paper addresses the innovations in higher education by integration of technology in various aspects of higher education in the present scenario.

\section{KEYWORDS: Education Technology, e-Learning, Education Technology in India}

\section{INTRODUCTION}

Creativity and innovation is the essence of teaching and learning in professional and conventional courses. Innovative teaching technique also emphasizes the importance of establishing a community of learners in which teachers and students share the responsibility for defining and achieving the learning goals of the entire group. The term technology means that all kinds of media and Information and Communication technology (ICT) in higher education for teaching and learning purpose. In $21^{\text {st }}$ century higher education in the country is experiencing a major transformation in terms of access, equity and quality. ICT is a diverse set of technological tools and resources used to communicate and to create, disseminate, store and manage information. This broad definition of ICT includes technologies as radio, television, video, DVD, telephone, satellite systems, computer and network hardware and software; as well as the equipment and services associated with these technologies, such as videoconferencing and electronic mail (UNESCO, 2002). Educational technology is the study and ethical practice of facilitating e-learning, which is the learning and improving performance by creating, using and managing appropriate technological processes and resources [14]. It is necessary to acquire the ability to use technology as a tool to research, organize, evaluate and communicate information and the possession of the fundamental understanding of the ethical or legal issues and use of information [1] [6] [9].

\section{Innovations in Higher Education using Technology : [2] [11]}

Education is a very powerful instrument for social change and transformation. Innovative teaching practice is the only way to enhance the quality of our education. Because of the rapid growth in technology, the present generation students are expecting more and varied knowledge more from teacher which causes the innovative teaching and learning process in higher education. In order to create a deeper learning, the focus must shift from 'talk and chalk' to how students learn and requires a deep approach to learning by giving students varied innovative stimulating learning 
environments in order to create a deeper learning. The use of innovative methods in educational institutions has the potential to improve education, to develop creativity, empower people, strengthen governance and galvanize the effort to achieve the human development goal for the country. The traits required of the innovative lecturer include humility, courage, impartiality, open-mindedness, empathy, enthusiasm, judgment and imagination. By the use of innovative teaching methodologies, students learn by doing themselves. Task of teacher is to facilitate learning and to motivate, encourage and mentor students to achieve knowledge and promote interest in their subject with the use of innovative methods. There is a shift from a teacher as a knowledge transmitter to a learning facilitator, collaborator, coach and knowledge navigator.

\section{Approaches of Technology in Higher Education:}

$>$ The Technology Literacy Approach: It indicates increasing the extent to which new technology is used by students by incorporating technology skills into the curriculum.

$>$ The Knowledge Deepening Approach: It indicates increasing the ability of students to use knowledge to add value to society and the economy by applying it to solve complex and real-world problems.

$>$ The Knowledge Creation Approach: It indicates increasing the ability of students to innovate and produce new knowledge and benefit from this new knowledge.

\section{Innovative Teaching and Learning Techniques using} Technology :

Innovative teaching and learning technique emphasizes the importance of establishing a community of learners in which teachers and students share the responsibility for defining and achieving the learning goals of the entire group. The Ministry of HRD has insisted that all educational institutions to use technology in classroom. Appropriate use of technology can catalyze the paradigmatic shift in both content and pedagogy that is at the heart of education reform in the $21^{\text {st }}$ century. These innovative ways of teaching and learning constitute a shift from a teacher-centered pedagogy to one that is learner-centered. While technology increasingly play a major role in disrupting legacy education models, it will equally place heightened emphasis on human beings' capacity to create and innovate in the face of rapid change and complexity. An innovative effort of an institution helps in its academic excellence. Innovative methods in higher education with the help of print media, audio media, audio-visual media, telecommunication and multimedia communication etc. are the different stages of the use of technology in educational transaction in higher educational institutes. (6)

A. Web-based Instruction: It is a form of innovative approach for delivering instruction to a remote audience in which the web is included as a tool . Presently, several web sites have been developed to provide learners with access to instructional resources from a distance.

B. Multimedia Learning : The opportunities associated with the development of computer-based technology provides the multimedia software available on CD-ROM plays a powerful role with applications in labs and lectures, tutorials and project work and specially useful in science subjects. The technologies include Adobe Photoshop and Premier to create and edit graphics and video files . Use of Sound Forge and 3D Studio Max helps to create and edit sound and animation files.

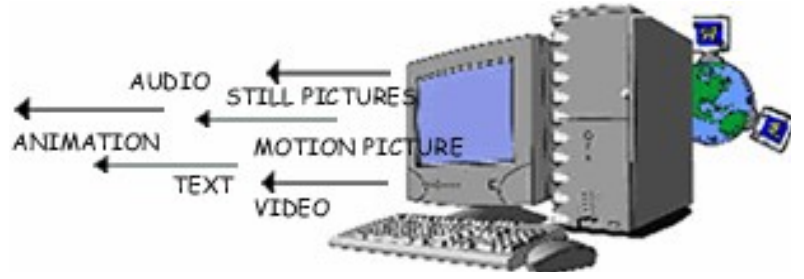

C. Teleconferencing: It is a new mixed model approach which combines satellite teleconferencing with hands-on activity session. It uses live teleconference speakers, video clips, interactive call-in sessions and local sessions.

D. Subject-quiz: It is an innovative teaching method which can be applicable to all the disciplines of teaching.

E. Blogging: Blogging assist the teacher to keep an ongoing personal record of their actions, decisions and issues they have to deal with. The blog can act as a kind of mirror and crystallize our ideas.

F. MO0C Courses: MOOC is the most popular way used to offer online courses globally. MOOC are the massive course designed to support unlimited participation and are offered through a platform. Currently, NPTEL, mooKIT, IITBX, and SWAYAM are the platforms used in India which offer different courses.

G. Podcast in Classroom: Podcasts are serial recordings which are posted online regularly. Producing podcast is a technology based equivalent of oral lectures which is flexible and reusable.

H. Screen cast: Screen cast is an effective teaching tool on the internet. Screen casts can be used for describing a step-by-step process, explaining a particular concept, or presenting a PowerPoint presentation with narration and multimedia elements.

I. Social Media: A social media where individuals are in communities that share ideas and interests. Some popular communities are Face book, MySpace, YouTube, blogs, Twitter and delicious. Face book and other social media delivers the promise of new, socially engaged educational experiences for students in undergraduate, self-directed, and other educational sectors.

J. Smartpens: Smartpens are used to capture transmitted information, replay it and sent it. It is like wireless transfer of your ideas anywhere, anytime and ready to share with students and vice versa. During lecture, smartpens help students, when teacher talk fast, student can record and understand all the left out things. Smartpens can record video, audio and diagrams which students can listen and understand during lecture.

K. Wikipedia: Wikipedia provides opportunity to the students to write articles and transforms students into teachers. It provides an ongoing project of developing knowledge for future generation of students.

Host course in Wikiversity:

$>$ Wikimedia -a non-profit foundation

$>$ Wikibooks -Offers free text books

$>$ Wikispecies -Provides dictionary of species

$>$ Wikiversity -Provides space for hosting courses or other content

L. Moodle: It is Open source system which helps to design your session. Moodle is Virtual Learning Environment which provides staff and students with access to electronic teaching and learning materials such as lecture notes and links to useful websites and activities such as 
International Journal of Trend in Scientific Research and Development (IJTSRD) @ www.ijtsrd.com eISSN: 2456-6470

discussion forums, group assignments, reflective journals and quizzes.

5. Measures Required for Innovations in Higher education using Technology: [7] [10] [13]

A. Before starting technology based teaching and learning activity, a research need to be conducted on the availability and quality of the physical and human resources.

B. There is a need of networking through Local Area Network (LAN), Wide Area Network (WAN), Information and Library Network(INFLIBNET) which would lead to increased academic activities and research.

C. Preparation of policy and master plan is a pre-requisite to successful mobilization of funds for implementation of technology based education.

D. Recurrent cost of software licenses like applications for the main information systems, specialized applications, database platforms, and desk top applications need to be considered.

E. Quality of content development for technology based educational material need to be checked. For this training should be conducted for educational content development specialist such as instructional designers, scriptwriters, audio and video production specialist, programmers \& web developers.

\section{Conclusion}

Innovations in higher education is possible by integration of technology. In the coming years, the thrust will be on the use of technology to strengthen the system in the mode of open and distance learning. Teacher has to adapt innovations in teaching by the use of technology for continuous professional development. Institutional and sector-wide higher education policy and planning should identify the specific role of technology in enhancing research capabilities and provide for adequate infrastructure backed by capacity building. Innovations in technology introduces digital libraries, access to online database and networking which can be enhanced through inter-institutional collaboration to ensure optimal usage of technology expertise and resources. Technology supported education can promote the acquisition of the knowledge and skills that will empower students for lifelong learning.. As the government increases its investments in technology for education, continued efforts must be made to ensure that investments in technology positively impact all aspects of education. Technology enabled education will definitely lead to the innovations in higher education in teaching and learning process.

\section{REFERENCES:}

[1] A. Garcia-Valcarcel Munoz-Repiso, F. J. Tejedor , 'Use of Information and Communication Technology in Higher Education and Lecturers' Competencies,'.

[2] Asha Kanwar, 'ICT in Higher Education: Who Stands to Gain?,'- Commonwealth of Learning.

[3] Chinmoy Goswami(2014) "Role of Technology in Indian Education”, DOI: 10.7763/IPEDR. , V79.2.

[4] C. M. Khairnar(2015). "Advance Pedagogy: Innovative Methods of Teaching and Learning", International Journal of Information and Education Technology, Vol. 5, No.11.
[5] Dillon, C. L. \& Walsh, S. M. (2001). "Faculty: The neglected resource in distance education." Teaching and learning in higher education, ASHE Reader Series.

[6] F F Tusubira and N Mulira, "Integration of ICT in Higher education Institutions: Challenges and best practice recommendations based on the experience of Makerere University and other organisations," Directorate for ICT Support Makerere University.

[7] Imran Hussain, M. Afshar Alam, Niloufer A. Kazmi (2011). "Promotion of elearning through ICT: Role of Indian government and higher educational Institutions", University News, 49(39), September 26-Oct 02, 2011.

[8] Krishna,V V (2007). "Universities and Emerging National Innovation Systems", South Asian (Indian) Experience".

[9] K. Balasubramanian, Willie Clarke-kah (2009). "ICTs for Higher Education,' Background paper from the Commonwealth of Learning UNESCO World Conference on Higher Education Paris.

[10] Kalpana Kumari(2012). "Modern and innovative practices and impact on teacher education", International Journal of Multidisciplinary Educational Research", Volume 1, Issue 2, ISSN: 2277:7881.

[11] MIAO Fengchun, "Constructive Approach to ICT in Education", APEID UNESCO Bankok.

[12] Neeru Snehi (2009). "ICT in Indian Universities and Colleges: Opportunities and Challenges", Management and Change, Volume 13, Number 2.

[13] Prasenjit Das, Ritimoni Bordoloi (2012). "Effectiveness of Open and Distance Education and the Relevance of ICT: A North-East Indian Perspective", Information and Knowledge Management, Vol.2, No.1.

[14] Richey, R. C. (2008). "Reflections on the 2008 AECT, Definitions of the Field. Tech Trends.

[15] Ron Oliver, "The role of ICT in higher education for the 21st century: ICT as a change agent for education", Edith Cowan University, Perth, Western Australia.

[16] Ulka Toro (2014). "Role of ICT for Teaching and Learning in Higher Education", International Journal of Research in Computer Science and Information Technology (IJRCSIT, Volume II, ISSN: 2319-5010, Issue II, Pg No. 140-142.

[17] Wright, C.(2000) "Issues in Education and Technology Policy Guidelines and Strategies." Commonwealth Secretariat, London.

\section{Internet Websites:}

1. http://www.google.com/

2. http://www.nkn.in/

3. http://www.sakshat.ac.in/

4. http://www.ugc.ac.in/

5. http://infomine.ucr.edu/

6. http:// citeseer.com/

Copyright (C) 2019 by author(s) and International Journal of Trend in Scientific Research and Development Journal. This is an Open Access article distributed under the terms of the Creative Commons Attribution License (CC BY CC 4.0) (http://creativecommons.org/licenses/by/4.0) 